\title{
HUBUNGAN ANTARA FONTANELA ANTERIOR DENGAN LINGKAR KEPALA PADA ANAK USIA KURANG DARI 18 BULAN DI POLIKLINIK ANAK RSUP SANGLAH DENPASAR
}

I Gusti Ayu Made Dwi Mas Istri ${ }^{1}$, Dewi Sutriani Mahalini ${ }^{2}$

${ }^{1}$ Program Studi Pendidikan Dokter, Fakultas Kedokteran Universitas Udayana

${ }^{2}$ Bagian/SMF Ilmu Kesehatan Anak, Fakultas Kedokteran Universitas Udayana/ RSUP Sanglah Denpasar Email: dwimas080494@gmail.com

\begin{abstract}
ABSTRAK
Evaluasi terhadap fontanela anterior (FA) dan lingkar kepala (LK) dilakukan dalam pemantauan proses tumbuh kembang anak. Studi mengenai hubungan FA dengan LK pada anak masih sangat terbatas. Penelitian ini bertujuan untuk mengetahui hubungan antara FA dengan LK pada anak usia kurang dari 18 bulan di Poliklinik Anak RSUP Sanglah Denpasar. Penelitian ini menggunakan rancangan potong lintang dengan sampel anak usia kurang dari 18 bulan yang datang ke Poliklinik Anak RSUP Sanglah Denpasar pada Juni-November 2015. Analisis korelasi dan regresi linear sederhana dilakukan untuk mengetahui hubungan antara diameter anteroposterior (AP) FA dengan LK, diameter transversal FA dengan LK, serta luas FA dengan LK. Hasil analisis terhadap data 87 subyek menunjukkan terdapat kecenderungan berkurangnya ukuran FA seiring dengan bertambahnya ukuran LK. Diameter AP FA dengan LK memiliki korelasi negatif $(\mathrm{r}=-0,327 ; \mathrm{p}=0,002)$ yang lebih kuat dibandingkan dengan korelasi negatif antara diameter transversal FA dengan lingkar kepala $(r=-0,199 ; \mathrm{p}=0,064)$ dan luas FA dengan LK $(\mathrm{r}=-$ 0,$258 ; \mathrm{p}=0,016$ ). Persamaan regresi linear untuk memperkirakan LK adalah $\mathrm{Y}=41,454-0,347 \mathrm{X}$ (dengan $\mathrm{Y}$ adalah LK dan X adalah luas FA).
\end{abstract}

Kata kunci: fontanela anterior, lingkar kepala, tumbuh kembang

\section{ABSTRACT}

Evaluation of anterior fontanel (AF) and head circumference (HC) usually done in children to monitor their growth and development. Exploration of the data in this study will reveal the correlation between AF and $\mathrm{HC}$ in children less than 18 months old at Poliklinik Anak RSUP Sanglah Denpasar. This was a cross-sectional study which involved children less than 18 months old in Poliklinik Anak RSUP Sanglah Denpasar on June-November 2015. Correlation and simple linear regression analysis between anteroposterior (AP) diameter of $\mathrm{AF}$ and $\mathrm{HC}$, transversal diameter of $\mathrm{AF}$ and $\mathrm{HC}$, and the size of $\mathrm{AF}$ and $\mathrm{HC}$ were performed in this study. Analysis result of 87 subject's data shows a tendency of AF size to decrease with the increase of $\mathrm{HC}$. AP diameter of AF shows strongest negative correlation with $\mathrm{HC}$ ( $\mathrm{r}=-$ 0.327; $\mathrm{p}=0.002)$, compared to transversal diameter of $\mathrm{AF}$ with $\mathrm{HC}(\mathrm{r}=-0.199 ; \mathrm{p}=0.064)$ and size of $\mathrm{AF}$ with $\mathrm{HC}(\mathrm{r}=-0.258 ; \mathrm{p}=0.016)$. The linear regression models to estimate $\mathrm{HC}$ is $\mathrm{Y}=41.454-0.347 \mathrm{X}$ (with $\mathrm{Y}$ is $\mathrm{HC}$ and $\mathrm{X}$ is size of $\mathrm{AF})$.

Keywords: anterior fontanel, head circumference, growth and development

\section{PENDAHULUAN}

Lingkar kepala (LK) dan fontanela anterior (FA) merupakan parameter tumbuh kembang yang penting untuk dinilai secara berkala karena dapat mencerminkan volume intrakranial dan merupakan refleksi penting tumbuh kembang otak pada awal masa kanakkanak. ${ }^{1,2}$

Ukuran dan bentuk kepala dapat memberi petunjuk penting yang mengarahkan ke suatu diagnosis banding. ${ }^{3}$ Sekitar 50\% pertambahan LK sejak lahir hingga dewasa terjadi pada dua tahun pertama kehidupan. ${ }^{1}$

Penelitian Tel Aviv Development Center menunjukkan dari 1393 anak, 15,4\% mengalami mikrosefali, $83,2 \%$ normosefali, dan $1,4 \%$ makrosefali. ${ }^{4}$ Ukuran kepala mikrosefali dan makrosefali sering terjadi bersamaan dengan kelainan lain pada anak, seperti cerebral palsy, kejang, keterlambatan perkembangan dan kecacatan intelektual. 5,6

Pemeriksaan FA juga digunakan untuk menilai tumbuh kembang, terutama terkait dengan pertumbuhan otak anak. Integritas hemisfer serebral didapat dengan melakukan palpasi pada sutura kranial utama dan merasakan adanya penggelembungan ataupun tumpang tindih sutura skuamosa yang menjadi penanda adanya gangguan pertumbuhan otak anak. Fontanela anterior menutup sekitar usia sembilan hingga 18 bulan. $^{3}$

Terdapat kemungkinan adanya hubungan antara diameter FA dengan LK anak, mengingat keduanya digunakan sebagai perkiraan pertumbuhan otak ataupun adanya gangguan tumbuh kembang lain pada anak. Studi yang membahas hubungan antara FA dengan LK juga 


\section{$\cap \bigcirc \triangle$ DIRECTORY OF}

masih sangat terbatas. Oleh karena itu penelitian ini dirasa perlu dilakukan oleh peneliti.

Anak usia kurang dari 18 bulan dengan riwayat kelahiran aterm dipilih sebagai populasi sampel karena diharapkan pada usia kurang dari 18 bulan FA masih terbuka. Anak dengan riwayat kelahiran aterm dipilih sebagai sampel untuk memudahkan pengklasifikasian ukuran LK karena terdapat perbedaan cara penafsiran ukuran LK antara anak dengan riwayat kelahiran preterm dan aterm. Poliklinik Anak RSUP Sanglah Denpasar dipilih sebagai lokasi penelitian karena dirasa dapat mencerminkan demografi anak usia kurang dari 18 bulan di Bali.

\section{BAHAN DAN METODE}

Penelitian ini menggunakan rancangan potong lintang dengan melakukan observasi terhadap diameter AP, transversal, dan luas FA serta ukuran LK pada anak usia kurang dari 18 bulan di Poliklinik Anak RSUP Sanglah Denpasar pada Juni-November 2015. Sampel pada penelitian ini dipilih dengan metode nonprobability convenient sampling. Data penelitian diperoleh dengan melakukan pengukuran langsung pada 135 anak, wawancara terhadap orang tua, serta data sekunder dari hasil pencatatan rekam medis. Pada penelitian ini juga dilakukan control by analysis dengan melakukan pengelompokan berdasarkan jenis kelamin.

Pada penelitian ini data yang diperoleh dianalisis menggunakan software SPSS 17.0, meliputi analisis univariat dan analisis bivariat dengan uji korelasi dan uji regresi linear sederhana.

\section{HASIL}

Pada 135 anak yang memenuhi kriteria inklusi, 28 diantaranya memiliki riwayat kelahiran preterm dan dieksklusi dari penelitian. Setelah dilakukan pemetaan LK pada kurva Nellhaus, 17 anak dengan mikrosefali dan tiga anak dengan makrosefali dieksklusi dari penelitian. Terdapat total 87 anak memenuhi kriteria inklusi dan tidak tereksklusi yang dijadikan subyek penelitian seperti yang dijabarkan pada Tabel 1 .
Tabel 1. Karakteristik Subyek Penelitian

\begin{tabular}{cc}
\hline \multicolumn{1}{c}{ Karakteristik } & $\mathrm{n}=87$ \\
\hline Jenis kelamin, laki-laki, $\mathrm{n}(\%)$ & $49(56,3)$ \\
Usia (bulan), mean \pm SD & $4,49 \pm 4,27$ \\
Berat badan $(\mathrm{kg})$, mean \pm SD & $6,03 \pm 2,28$ \\
Panjang badan (cm), mean \pm SD & $61,28 \pm 8,77$ \\
Lingkar kepala (cm), mean \pm SD & $39,42 \pm 3,91$ \\
Status gizi, n $(\%) *$ & \\
BB/U Gizi buruk & $3(3,4)$ \\
$\quad$ Gizi kurang & $3(3,4)$ \\
Gizi baik & $77(88,5)$ \\
Gizi lebih & $4(4,6)$
\end{tabular}

*status gizi berdasarkan Departemen Kesehatan Republik Indonesia.

Proporsi subyek berjenis kelamin lakilaki $(56,3 \%)$ lebih besar dari jenis kelamin perempuan $(43,7 \%)$ dengan usia subyek penelitian berada pada rentang 2,93 (0,10$16,43)$ bulan.

Setelah dilakukan analisis univariat maka ditemukan gambaran diameter AP FA, diameter transversal FA, dan luas FA pada subyek penelitian.

Pada subyek berjenis kelamin laki-laki, diameter AP FA berada pada rentang 3,50 $(1,40-5,20) \mathrm{cm}$, dan pada jenis kelamin perempuan berada pada rentang 3,00 (1,20$5,20) \mathrm{cm}$. Pada kedua kelompok jenis kelamin, terdapat kecenderungan penurunan ukuran diameter AP FA seiring dengan bertambahnya usia. Scatter plot diameter AP FA berdasarkan jenis kelamin dan usia dapat dilihat pada Gambar 1A

Diameter transversal FA pada subyek berjenis kelamin laki-laki berada pada rentang $3,60(1,50-5,00) \mathrm{cm}$, dan pada jenis kelamin perempuan berada pada rentang 3,15 (1,60$6,00) \mathrm{cm}$. Pada kedua kelompok jenis kelamin, terdapat kecenderungan penurunan ukuran diameter transversal FA seiring dengan bertambahnya usia. Scatter plot diameter transversal FA berdasarkan jenis kelamin dan usia dapat dilihat pada Gambar 1B

Luas FA pada subyek laki-laki berada pada rentang 6,00 $(1,33-11,96) \mathrm{cm}$, dan pada jenis kelamin perempuan berada pada rentang $4,93(0,96-15) \mathrm{cm}$ 


\section{DOAJ DIRECTORY OF}

Terdapat kecenderungan penurunan luas FA seiring dengan bertambahnya usia pada kelompok subyek berjenis kelamin laki-laki dan perempuan. Scatter plot luas FA berdasarkan jenis kelamin dan usia dapat dilihat pada Gambar 1C.

Distribusi masing-masing variabel diketahui melalui uji Kolmogorov-Smirnov, kemudian dilakukan analisis bivariat uji hipotesis hubungan antara diameter AP FA dengan LK, diameter transversal FA dengan LK, dan luas FA dengan LK pada anak usia kurang dari 18 bulan dengan uji korelasi Pearson. Analisis bivariat secara lebih lanjut dilakukan dengan membedakan subyek menjadi dua kelompok berdasarkan jenis kelamin, lakilaki dan perempuan. Distribusi masing-masing variabel pada kelompok jenis kelamin laki-laki dan perempuan diketahui melalui uji ShapiroWilk. Uji korelasi antara diameter AP FA dengan LK, diameter transversal FA dengan LK dan luas FA dengan LK dapat dilihat pada Tabel 2.
Hasil analisis bivariat Pearson Test menunjukkan adanya hubungan lemah negatif yang bermakna secara statistik antara diameter AP FA dengan LK ( $r=-0,327 ; \mathrm{p}=0,002)$. Hubungan bersifat negatif, artinya terjadi hubungan berlawanan arah antara diameter AP FA dengan LK. Analisis korelasi pada jenis kelamin laki-laki menunjukkan adanya hubungan secara sangat lemah negatif antara diameter AP FA dengan LK yang tidak bermakna secara statistik $(r=-0,195 ; \mathrm{p}=0,179)$, sedangkan pada jenis kelamin perempuan didapatkan hubungan (korelasi) cukup negatif yang bermakna secara statistik $(r=-0,512$; $\mathrm{p}=0,001)$.

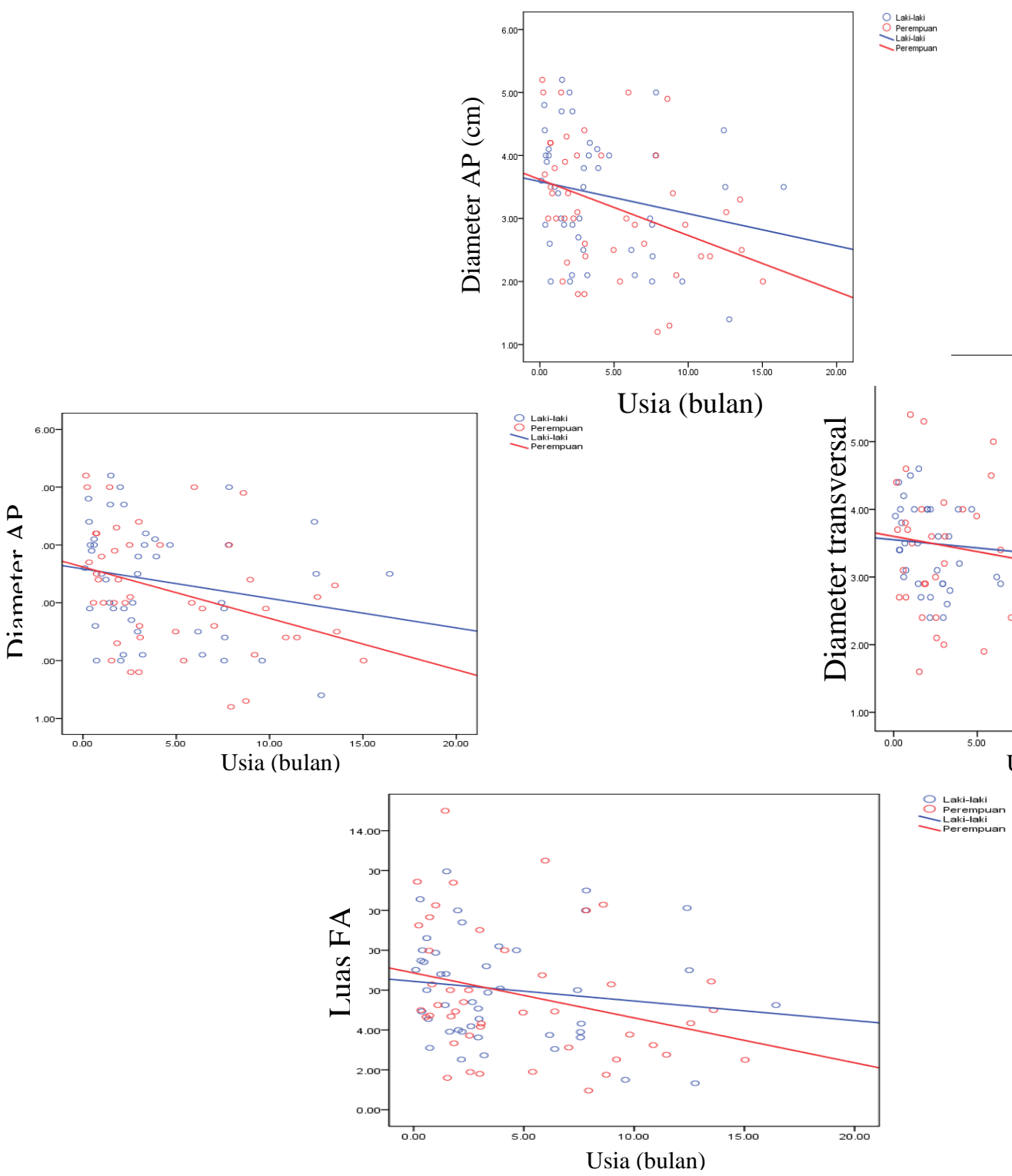


Gambar 1. Scatter plot diameter AP FA (A), diameter transversal FA (B) dan luas FA (C) berdasarkan jenis kelamin dan usia.

Terdapat hubungan secara sangat lemah negatif yang tidak bermakna secara statistik antara diameter transversal FA dengan LK ( $\mathrm{r}=-0,199 ; \mathrm{p}=0,064)$. Pada jenis kelamin Tabel 2. Uji Korelasi Diameter AP FA, Diameter Transversal FA dan Luas FA dengan LK.

\begin{tabular}{llcc}
\hline \multirow{2}{*}{ Fontanela Anterior (FA) } & \multicolumn{1}{c}{ Subyek } & \multicolumn{2}{c}{ Lingkar Kepala } \\
\cline { 3 - 4 } Diameter AP & Seluruh subyek $(\mathrm{n}=87)$ & $-0,327^{\mathrm{a}}$ & $0,002^{*}$ \\
& Laki-laki $(\mathrm{n}=49)$ & $-0,195^{\mathrm{a}}$ & 0,179 \\
& Perempuan $(\mathrm{n}=38)$ & $-0,512^{\mathrm{b}}$ & $0,001^{*}$ \\
& & & \\
Diameter Transversal & Seluruh subyek $(\mathrm{n}=87)$ & $-0,199^{\mathrm{a}}$ & 0,064 \\
& Laki-laki $(\mathrm{n}=49)$ & $-0,180^{\mathrm{a}}$ & 0,217 \\
& Perempuan (n=38) & $-0,238^{\mathrm{b}}$ & 0,150 \\
Luas & Seluruh subyek (n=87) & $-0,258^{\mathrm{a}}$ & $0,016^{*}$ \\
& Laki-laki $(\mathrm{n}=49)$ & $-0,167^{\mathrm{a}}$ & 0,252 \\
& Perempuan $(\mathrm{n}=38)$ & $-0,400^{\mathrm{b}}$ & $0,013^{*}$ \\
\hline
\end{tabular}

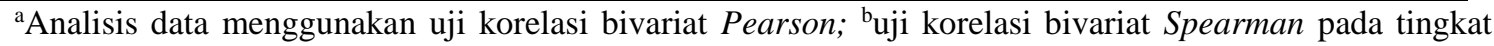
kemaknaan $\mathrm{p}<0,05$.

$*$ Nilai $\mathrm{p}<0,05$.

perempuan didapatkan hubungan (korelasi) secara lemah negatif namun tidak bermakna secara statistik $(r=-0,238 ; \mathrm{p}=0,150)$.

Hubungan lemah negatif yang bermakna secara statistik didapatkan antara luas FA dengan LK ( $\mathrm{r}=-0,258 ; \mathrm{p}=0,016)$. Pada jenis kelamin laki-laki terdapat hubungan secara sangat lemah negatif antara luas FA dengan LK yang tidak bermakna secara statistik $(r=-0,167$; $\mathrm{p}=0,252$ ), sedangkan pada jenis kelamin perempuan didapatkan hubungan cukup negatif yang bermakna secara statistik ( $\mathrm{r}=-0,400$; $\mathrm{p}=0,013$ ).

Analisis regresi digunakan untuk mengidentifikasi variabel bebas dengan memperhitungkan pengaruh variabel-variabel lain secara bersama-sama. Model regresi digunakan untuk dapat memperkirakan nilai variabel terikat berdasarkan pada nilai variabel laki-laki terdapat hubungan secara sangat lemah negatif antara diameter transversal FA dengan LK yang tidak bermakna secara statistik ( $\mathrm{r}=-$ $0,180 ; p=0,217)$, sedangkan pada jenis kelamin 
Tabel 3. Uji Regresi Linear Sederhana Diameter AP FA, Diameter Transversal FA dan Luas FA dengan LK.

\begin{tabular}{llcccccc}
\hline \multicolumn{1}{c}{ FA } & \multicolumn{1}{c}{ Subyek } & Sig. & $\mathrm{R}$ & Konstanta & $\begin{array}{c}\text { Interval } \\
\text { Kepercayaan } \\
95 \%\end{array}$ & $\begin{array}{c}\text { Koef. } \\
\text { Reg. }\end{array}$ & $\begin{array}{c}\text { Interval } \\
\text { Kepercayaan } \\
95 \% \text { untuk } \\
\text { Koef. Reg. }\end{array}$ \\
\hline Diameter & Seluruh subyek & 0,002 & 0,327 & 43,694 & $40,918-46,471$ & $-1,304$ & $-2,116-(-0,492)$ \\
AP & Laki-laki & 0,179 & 0,195 & 42,257 & $38,032-46,482$ & $-0,820$ & $-2,027-0,388$ \\
& Perempuan & 0,002 & 0,493 & 45,238 & $41,534-48,942$ & $-2,994$ & $-2,994-(-0,757)$ \\
Diameter & Seluruh subyek & 0,064 & 0,199 & 42,349 & $39,141-45,557$ & $-0,860$ & $-1,771-0,051$ \\
Transversal & Laki-laki & 0,217 & 0,180 & 42,771 & $37,385-48,158$ & $-0,943$ & $-2,456-0,571$ \\
& Perempuan & 0,166 & 0,229 & 42,092 & $37,929-46,255$ & $-0,835$ & $-2,034-0,364$ \\
Luas & & & & & & & \\
& Seluruh subyek & 0,016 & 0,258 & 41,454 & $39,622-43,286$ & $-0,347$ & $-0,627-(-0,066)$ \\
& Laki-laki & 0,252 & 0,167 & 41,058 & $38,116-44,001$ & $-0,258$ & $-0,707-0,190$ \\
& Perempuan & 0,028 & 0,357 & 41,685 & $39,270-44,101$ & $-0,791$ & $-0,791-(-0,049)$ \\
\hline
\end{tabular}

penambahan ukuran LK untuk setiap pengurangan diameter AP FA.

Hasil analisis regresi linear sederhana yang dilakukan pada masing-masing kelompok jenis kelamin menunjukkan bahwa pada jenis kelamin laki-laki model regresi linear sederhana tidak dapat digunakan untuk memprediksi LK yang dipengaruhi oleh diameter AP FA karena didapatkan $F_{\text {hitung }}(1,865)<\mathrm{F}_{\text {tabel }}(4,047)$ dan nilai signifikansi $(0,179)>a(0,05)$. Pada jenis kelamin perempuan, didapatkan $F_{\text {hitung }}(11,558)$ $>\mathrm{F}_{\text {tabel }}(4,113)$ dan nilai signifikansi $(0,002)<\mathrm{a}$ $(0,05)$ yang menunjukkan bahwa pada jenis kelamin perempuan, model regresi linear sederhana dapat digunakan untuk memprediksi LK yang dipengaruhi oleh diameter AP FA. Persamaan regresi linear untuk memperkirakan LK yang dipengaruhi oleh diameter AP FA pada jenis kelamin perempuan adalah:

$\mathrm{Y}=45,238-1,875 \mathrm{X}$ (dengan $\mathrm{Y}$ adalah LK dan $\mathrm{X}$ adalah diameter AP FA). Koefisien regresi 1,875 mengindikasikan besaran pengurangan ukuran LK untuk setiap penambahan diameter AP FA dan begitu pula sebaliknya, mengindikasikan besaran penambahan ukuran LK untuk setiap pengurangan diameter AP FA.

Pada analisis regresi linear sederhana antara diameter transversal FA dengan LK pada seluruh subyek penelitian didapatkan $\mathrm{F}_{\text {hitung }}$ $(3,522)<\mathrm{F}_{\text {tabel }}(3,953)$ dan nilai signifikansi $(0,064)>a(0,05)$ yang menunjukkan bahwa model regresi linear sederhana tidak dapat digunakan untuk memprediksi LK yang dipengaruhi oleh diameter transversal FA. Pada jenis kelamin laki-laki dan perempuan, model regresi linear sederhana tidak dapat digunakan untuk memprediksi LK yang dipengaruhi oleh diameter transversal FA. Pada laki-laki didapatkan $F_{\text {hitung }}(1,569)<F_{\text {tabel }}(4,047)$ dan nilai signifikansi $(0,217)>a(0,05)$, sedangkan perempuan, didapatkan $F_{\text {hitung }}(1,996)<\mathrm{F}_{\text {tabel }}$ $(4,113)$ dan nilai signifikansi $(0,166)<a(0,05)$.

Uji regresi linear sederhana antara luas FA dengan LK pada seluruh subyek penelitian didapatkan $F_{\text {hitung }}(6,051)>F_{\text {tabel }}(3,953)$ dan nilai signifikansi $(0,016)<a(0,05)$ yang menunjukkan bahwa model regresi linear sederhana dapat digunakan untuk memprediksi LK yang dipengaruhi oleh luas FA. Persamaan regresi linear untuk memperkirakan LK yang dipengaruhi oleh luas FA adalah:

$\mathrm{Y}=41,454-0,347 \mathrm{X}$ (dengan Y adalah LK dan $\mathrm{X}$ adalah luas FA. Koefisien regresi $-0,347$ mengindikasikan besaran pengurangan ukuran LK untuk setiap penambahan luas FA dan begitu pula sebaliknya mengindikasikan besaran penambahan ukuran LK untuk setiap pengurangan luas FA.

Pada jenis kelamin laki-laki model regresi linear sederhana tidak dapat digunakan untuk memprediksi LK yang dipengaruhi oleh luas fontanela anterior karena didapatkan $\mathrm{F}_{\text {hitung }}$ $(1,344)<\mathrm{F}_{\text {tabel }}(4,047)$ dan nilai signifikansi $(0,252)>a(0,05)$. Pada perempuan, $F_{\text {hitung }}$ $(5,26)>F_{\text {tabel }}(4,113)$ dan nilai signifikansi $(0,028)<\mathrm{a}(0,05)$ yang menunjukkan bahwa model regresi linear sederhana dapat digunakan untuk memprediksi LK yang dipengaruhi oleh luas FA. Persamaan regresi linear untuk memperkirakan LK yang dipengaruhi oleh luas FA pada perempuan adalah:

$\mathrm{Y}=41,685-0,420 \mathrm{X}$ (dengan $\mathrm{Y}$ adalah LK dan $\mathrm{X}$ adalah luas FA). Koefisien regresi $-0,420$ mengindikasikan besaran pengurangan ukuran LK untuk setiap penambahan luas FA dan begitu pula sebaliknya, mengindikasikan besaran penambahan ukuran LK untuk setiap pengurangan luas FA. 


\section{PEMBAHASAN}

Penelitian ini melibatkan 87 anak usia kurang dari 18 bulan di Poliklinik Anak RSUP Sanglah Denpasar dimana didapatkan proporsi subyek dengan laki-laki $(56,3 \%)$ lebih besar dibanding perempuan $(43,7 \%)$. Usia subyek penelitian sangat bervariasi antara $0,1-16,43$ bulan, dimana pada penelitian ini tidak dilakukan pengelompokan berdasarkan usia.

Pada subyek laki-laki, diameter AP FA berada pada rentang $3,50(1,40-5,20) \mathrm{cm}$, dan pada perempuan berada pada rentang 3,00 $(1,20-5,20) \mathrm{cm}$. Hal ini sejalan dengan hasil penelitian Tiansyah R.A, dkk ${ }^{7}$ yang melibatkan 250 subyek penelitian, didapatkan hasil yang tidak jauh berbeda, dimana pada subyek lakilaki median diameter FA didapatkan 2,17 (1,054,6 cm) dan pada subyek perempuan 2,22 $(1,35-$ 4,5) $\mathrm{cm}$. Pada penelitian Tiansyah R.A, dkk nilai median diameter FA pada jenis kelamin laki-laki juga ditemukan sedikit lebih besar dibandingkan perempuan.

Kurva scatter plot yang menggambarkan diameter AP, diameter transversal, dan luas FA terhadap usia (Gambar 1A, Gambar 1B, dan Gambar 1C) menunjukkan kecenderungan penurunan ukuran baik pada diameter AP, diameter transversal, dan luas FA seiring dengan bertambahnya usia. Hal ini sejalan dengan penelitian $\mathrm{Wu}, \mathrm{T}$ dan $\mathrm{Li}, \mathrm{H} . \mathrm{Q}^{8}$ dimana ukuran FA terbesar ditemukan saat anak baru lahir sampai dengan usia satu bulan, kemudian semakin berkurang seiring bertambahnya usia hingga akhirnya menutup secara sempurna.

Uji korelasi antara diameter AP FA dengan LK pada seluruh subyek penelitian menunjukkan hubungan lemah negatif yang bermakna secara statistik antara diameter AP FA dengan ukuran LK. Pada jenis kelamin lakilaki terdapat hubungan sangat lemah negatif yang tidak bermakna secara statistik, sedangkan pada perempuan terdapat hubungan cukup negatif yang bermakna secara statistik. FA merupakan suatu celah fibrosa yang dilindungi oleh membran, yang terbentuk saat dua atau lebih tulang cranial saling berjajar (juxtaposed), dan merupakan sambungan sempit yang terbentuk dari jaringan ikat fibrosa yang memisahkan tulang pipih pada tengkorak. ${ }^{9}$ Tulang tengkorak awalnya tidak menyatu sempurna untuk memberikan ruang bagi tumbuh kembang otak anak yang terjadi begitu pesat pada dua tahun pertama kehidupan. ${ }^{3,10} \mathrm{Hal}$ ini yang mungkin menyebabkan ukuran terbesar fontanela yang biasanya saat lahir hingga usia tiga bulan, dimana pada saat ini terjadi tumbuh kembang otak secara pesat, yang kemudian melambat seiring dengan berjalannya usia. ${ }^{1}$
Sampai saat ini belum terdapat penelitian di Indonesia mengenai bagaimana hubungan antara FA dengan LK.

Adanya perbedaan makna hasil uji statistik hubungan diameter AP FA dengan LK pada anak laki-laki dan perempuan mungkin disebabkan oleh perbedaan variasi usia subyek penelitian pada masing-masing kelompok jenis kelamin. Pada kelompok laki-laki dan perempuan mayoritas subyek memang berada pada rentang usia <3 bulan, namun jumlah subyek di masing-masing umur yang lain tersebar secara lebih merata pada kelompok perempuan. Sebaiknya pada penelitian selanjutnya dilakukan analisa secara terpisah sesuai kelompok umur pada sampel dengan jumlah subyek penelitian lebih besar.

Diameter transversal FA merupakan diameter FA yang diukur dari batas kiri ke batas kanan. Seperti halnya diameter AP FA, ukuran diameter transversal memiliki kecenderungan berkurang seiring dengan bertambahnya usia anak. Berbeda halnya dengan LK yang cenderung bertambah seiring dengan bertambahnya usia. Hal ini sejalan dengan hasil penelitian yang didapatkan peneliti, dimana terdapat hubungan negatif atau berlawanan arah dimana semakin kecil diameter transversal, maka ukuran LK akan semakin besar.

Uji korelasi antara diameter transversal FA dengan LK menunjukkan hasil yang tidak bermakna secara statistik yang mungkin disebabkan oleh terbatasnya jumlah sampel yang terlibat dalam penelitian ini serta sistem pemilihan sampel dengan metode convenient sampling dimana pengambilan data mayoritas dilakukan pada hari Jumat dan Sabtu yang merupakan jadwal kontrol untuk pasien-pasien tertentu, sehingga bisa memberikan bias dalam penelitian.

Luas FA didapatkan dari hasil perhitungan diameter AP dikalikan diameter transversal kemudian dibagi dua sehingga secara tidak langsung, luas FA mencerminkan diameter AP dan transversalnya. ${ }^{8,9}$ Uji korelasi luas FA dengan LK menunjukkan hubungan negatif, baik pada analisis seluruh subyek, subyek perempuan, dan subyek laki-laki. Perbedaan signifikansi hasil penelitian pada kelompok jenis kelamin laki-laki kemungkinan dipengaruhi oleh keterbatasan penelitian, dimana pada penelitian ini tidak dilakukan penggolongan sesuai usia subyek, sehingga jumlah subyek pada masing-masing kelompok umur pada kelompok laki-laki sangat jauh berbeda dan memungkinkan timbulnya bias penelitian. 
Uji regresi linear untuk memprediksikan LK berdasarkan diameter AP memiliki interval kepercayaan yang terbilang cukup lebar. Hal ini disebabkan karena jumlah sampel pada penelitian yang sangat terbatas. Untuk itu penelitian selanjutnya diharapkan menggunakan sampel dengan jumlah yang lebih besar sehingga analisis bisa melibatkan lebih banyak data sehingga interval kepercayaan dapat dipersempit.

Hasil uji regresi linear luas FA dan LK pada seluruh subyek penelitian diperoleh bahwa model regresi linear sederhana dapat digunakan untuk memprediksi ukuran LK yang dipengaruhi oleh luas FA. Model regresi linear sederhana juga dapat digunakan untuk memprediksi LK yang dipengaruhi oleh luas FA pada perempuan, namun tidak dapat dipergunakan pada laki-laki. Sama halnya seperti pada hasil uji korelasi, hal ini kemungkinan disebabkan jumlah subyek pada jenis kelamin laki-laki kurang tersebar secara merata pada masing-masing umur.

\section{SIMPULAN}

Diameter AP, diameter transversal, dan luas FA memiliki kecenderungan untuk berkurang seiring dengan bertambahnya usia. Pada keseluruhan subyek, terdapat hubungan lemah negatif yang bermakna antara diameter AP FA dengan LK, hubungan sangat lemah negatif yang tidak bermakna secara statistik antara diameter transversal dengan LK dan hubungan lemah negatif bermakna antara luas FA dengan LK. Model regresi linear sederhana dapat digunakan untuk memprediksi LK yang dipengaruhi oleh diameter AP atau luas FA, dengan persamaan $\mathrm{Y}=43,694-1,304 \mathrm{X}$ (dengan $\mathrm{Y}$ adalah $\mathrm{LK}$ dan $\mathrm{X}$ adalah diameter AP FA) atau dengan persamaan $\mathrm{Y}=41,454-$ $0,347 \mathrm{X}$ (dengan $\mathrm{Y}$ adalah LK dan $\mathrm{X}$ adalah luas FA).

\section{DAFTAR PUSTAKA}

1. Soetjiningsih. Tumbuh Kembang Anak. Jakarta: Penerbit Buku Kedokteran EGC. 2012. h. 1-23, 39-41

2. Bouthoorn, SH, Lenthe, FJV dkk. Head Circumference of Infants Born to Mothers with Different Educational Levels; The Generation R Study. PLoS ONE. 2012. 7(6): 397-98.
3. Menounou, Angeliki. Head Size: Is it important?. Paediatric Neurology ACNR. 2011; 11(2): 16-20

4. Watemberg, Nathan, Silver, Sarah dkk. Significance of Microcephaly Among Children With Developmental Disability. Journal of Child Neurology. 2013. 17(2): 117-22

5. Filipink, Robyn, Schor, Nina. Microcephaly. [serial online]. 2013. [diakses pada 15 Januari 2015] Diunduh dari URL: http://www.medlink.com/medlinkcontent.a sp.

6. Ververi, Athina, Vargiami, Efthyma dkk. Clinical and Laboratory Data in a Sample of Greek Children with Autism Spectrum Disorders. J Autism Dev Disord. 2012. 42: h. $1470-76$

7. Tiansyah, RA, Mangunatmadja, Irawan, Pulungan, AB. Head Circumference and Anterior Fontanel Measurements in Newborns. Paediatr Indones. 2012. 52: h. 145-51

8. $\mathrm{Wu}, \mathrm{T}, \mathrm{Li}, \mathrm{HQ}$. Changes of Anterior Fontanel Size in Children Aged 0-2 Years. Zhonghua Er Ke Za Zhi. 2012. 50(7): 4937

9. Kiesler, Joseph, Ricer, Rick. The Abnormal Fontanel. Afp. 2006. 67(12): h. 2547-52.

10. Knickmeyer, RC, Gouttard, Sylvain dkk. A Structural MRI Study of Human Brain Development from Birth to 2 Years. The Journal of Neuroscience. 2008. 18(47): h. 12176-82. 